\title{
Metabolism of Methionine in the Newborn Infant: Response to the Parenteral and Enteral Administration of Nutrients
}

\author{
BIJU THOMAS, LOURDES L. GRUCA, CAROLE BENNETT, PRABHU S. PARIMI, RICHARD W. HANSON, \\ AND SATISH C. KALHAN
}

\begin{abstract}
Department of Pediatrics [B.T., P.S.P.], MetroHealth Medical Center, Cleveland, Ohio 44109, Department of Medicine [L.L.G., C.B., R.W.H., S.C.K.], Cleveland Clinic Lerner College of Medicine, Cleveland, Ohio 44195, Department of Biochemistry [R.W.H.], Case Western Reserve University, Cleveland, Ohio 44106
\end{abstract}

\begin{abstract}
The rates of transmethylation and transsulfuration of methionine were quantified using $\left[1-{ }^{13} \mathrm{C}\right]$ methionine and $\left[\mathrm{C}^{2} \mathrm{H}_{3}\right]$ methionine tracers in newborn infants born at term gestation and in prematurely born low birth weight infants. Whole body rate of protein breakdown was also measured using $\left[{ }^{2} \mathrm{H}_{5}\right]$ phenylalanine. The response to enteral formula feeding and parenteral nutrition was examined in full term and prematurely born babies, respectively. The relative rates of appearance of methionine and phenylalanine were comparable to the amino acid composition of mixed body proteins. Rates of transmethylation were high, both in full term infants (fast $32 \pm 14 \mu \mathrm{mol} \mathrm{kg}{ }^{-1} \cdot \mathrm{h}^{-1}$; fed $\left.21.7 \pm 3.2\right)$ and in preterm infants (57.2 \pm 14.8$)$. Significant flux through the transsulfuration pathway was evident (full term: fast $6.0 \pm 4.4$, fed $4.1 \pm 2.1$; preterm: $\left.24.9 \pm 9.9 \mu \mathrm{mol} \mathrm{kg}{ }^{-1} \cdot \mathrm{h}^{-1}\right)$. Transsulfuration of methionine is evident in the human newborn in the immediate neonatal period, suggesting that cysteine may not be considered a "conditionally" essential amino acid for the neonate. The high rate of transmethylation may reflect the high methylation demand, whereas high rates of transsulfuration in premature babies may be related to high demands for glutathione and to the amounts of methionine in parenteral amino acid mixtures. (Pediatr Res 64: 381-386, 2008)
\end{abstract}

$\mathrm{M}$ ethionine, an essential amino acid, is also a source of methyl groups for a number of methylation reactions such as methylation of nucleic acids, proteins, biogenic amines, phospholipids, etc. Methionine is also a source for the cysteine required for the synthesis of glutathione $(1,2)$. Interest in the metabolism of methionine has remained high ever since it was observed that a key enzyme involved in the formation of cysteine from homocysteine (transsulfuration), cystathionine $\gamma$ lyase (CGL), is absent in the fetal liver and its activity appears for the first time in the immediate neonatal period (3-7). It has been suggested that the human fetus and neonate is unable to convert cystathionine to cysteine in significant quantities. Thus, cysteine has been suggested to be a "conditionally essential" amino acid for the neonate, and is often added to the parenteral amino acid mixtures, especially for prematurely born infants $(8,9)$. However, the development of the activity of CGL after birth, the impact of premature

Received January 15, 2008; accepted April 26, 2008.

Correspondence: Satish C. Kalhan, M.D., The Cleveland Clinic Foundation, Lerner Research Institute, Department of Pathobiology/NE 40, 9500 Euclid Avenue, Cleveland, OH 44195; e-mail: sck@case.edu

Supported by NIH grants RO1 HD042154, and MO1 RR00080. birth and of nutrient interventions on the transsulfuration of methionine is unknown.

The synthesis of cysteine from homocysteine and serine is regulated by an individual's nutrient state and by the relative concentration of insulin, glucagon and adrenal corticosteroids $(10-12)$. Insulin has a repressive effect on hepatic CGL and on cystathionine $\beta$ synthase (CBS), whereas glucagon and glucocorticoids increase the hepatic activity of these enzymes. Transition to extrauterine life is characterized by a decrease in plasma levels of insulin and a surge in plasma glucagon and catecholamines (13). In contrast, parenteral nutrition (amino acids plus glucose) increases plasma insulin and decreases the concentration of glucagon. The impact of adaptation during transition to extrauterine life and the effect of nutrient interventions on methionine metabolism have not been evaluated. In the present study, we have quantified the kinetics of methionine and its metabolism in healthy full term and prematurely born infants. Our data show that the human newborn develops the capacity to metabolize methionine via transsulfuration rapidly after birth.

\section{METHODS}

The study protocol was approved by the Institutional Review Board of MetroHealth Medical Center, Cleveland, Ohio. All studies were carried out after obtaining verbal assent from the attending neonatologist. Written informed consent was obtained from the parent(s) after fully explaining the procedure. The studies in full term infants were performed in the General Clinical Research Center, whereas studies in premature infants were performed in the neonatal intensive care unit.

Full term appropriate- for- gestation newborn infants $(n=18)$ were recruited from the newborn nursery (Table 1). They were all healthy and had no antenatal or neonatal problems. Their Apgar scores were within normal range and none were receiving antibiotics. All of them were receiving formula (SimilacRoss Pharmaceuticals, Columbus, Ohio) ad libitum every $3 \mathrm{~h}$ from birth.

Nine prematurely born neonates were recruited from the neonatal intensive care unit. Their Apgar scores were $>7$ at $5 \mathrm{~min}$ and the median score for neonatal acute physiology (SNAP), a marker of acuity of illness at birth (14), was 11 (25th-75th percentile: 6-16). The infants were all clinically stable, were either on minimal ventilator support or were receiving supplemental oxygen via nasal cannula. None were receiving vasopressors or glucocorticoids. All prematurely born babies were given ampicillin and gentamicin for $48 \mathrm{~h}$ for presumed sepsis.

Full term infants. Three hours after their last feed, two indwelling vascular catheters were placed, one on the dorsum of the hand for infusion of the tracer solution, and the other in the saphenous vein (Fig. 1A). After

Abbreviations: CBS, cystathionine $\beta$ synthase; CGL, cystathionine $\gamma$ lyase; Ra, rate of appearance; SAM, $S$-adenosylmethionine 
Table 1. Characteristics of subjects and nutritional data

\begin{tabular}{|c|c|c|c|c|c|c|c|}
\hline & $\begin{array}{l}\text { Gestational } \\
\text { age (wks) }\end{array}$ & $\begin{array}{l}\text { Birth wt } \\
\text { (gm) }\end{array}$ & $\begin{array}{l}\text { Age at } \\
\text { study (h) }\end{array}$ & $\begin{array}{l}\text { Weight at } \\
\text { study (gm) }\end{array}$ & $\begin{array}{c}\text { Protein } \\
\left(\mathrm{g} \cdot \mathrm{kg}^{-1} \cdot \mathrm{d}^{-1}\right)^{*}\end{array}$ & $\begin{array}{c}\text { Phenylalanine } \\
\left(\mu \mathrm{mol} \cdot \mathrm{kg}^{-1} \cdot \mathrm{h}^{-1}\right)^{*}\end{array}$ & $\begin{array}{c}\text { Methionine } \\
\left(\mu \mathrm{mol} \cdot \mathrm{kg}^{-1} \cdot \mathrm{h}^{-1}\right)^{*}\end{array}$ \\
\hline Full term $(n=18)$ & $39.1 \pm 1.5$ & $3315 \pm 503$ & $39 \pm 10$ & $3277 \pm 516$ & $2.4 \pm 0.1$ & $21.6 \pm 0.6$ & $14 \pm 0.4$ \\
\hline Preterm $(n=9)$ & $28.6 \pm 1.7$ & $1230 \pm 248$ & $73 \pm 14$ & $1155 \pm 248$ & $3.1 \pm 0.5$ & $30 \pm 5$ & $24 \pm 0.4$ \\
\hline
\end{tabular}

Data are mean \pm SD.

* Full term infants were fed commercial formula (Similac) while preterm infants were receiving parenteral nutrition (Trophamine) with added cysteine (40 $\mathrm{mg} / \mathrm{g}$ protein or $42 \pm 7 \mu \mathrm{mole} \cdot \mathrm{kg}^{-1} \cdot \mathrm{h}^{-1}$ ) and intralipid.

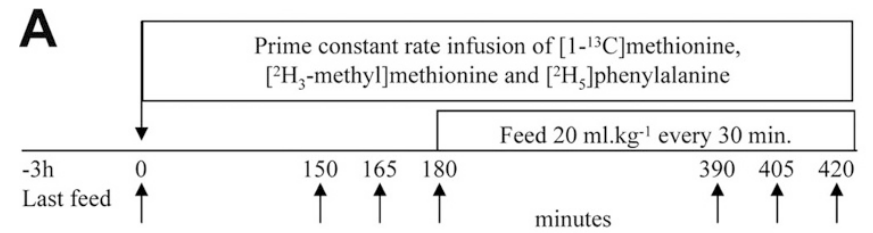

B

Prime constant rate infusion of $\left[1-{ }^{13} \mathrm{C}\right]$ methionine, $\left[{ }^{2} \mathrm{H}_{3}\right.$-methyl $]$ methionine and $\left[{ }^{2} \mathrm{H}_{5}\right]$ phenylalanine

Parenteral amino acids at $3 \mathrm{~g} \cdot \mathrm{kg}^{-1} \cdot \mathrm{d}^{-1}$

\section{$\uparrow$}

minutes

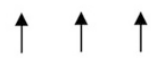

Figure 1. Study design. $A$, Full term infants. $B$, Preterm infants.

obtaining basal sample (time 0), tracer amino acid solution was infused for 7-h. Blood and breath samples were obtained during the basal state and after feeding. Every $30 \mathrm{~min}$, infants were fed $20 \mathrm{~mL} \cdot \mathrm{kg}^{-1}$ of infant formula (Similac in six equal aliquots. The formula provided methionine at $14 \pm 0.4$ $\mu \mathrm{mol} \cdot \mathrm{kg}^{-1} \cdot \mathrm{h}^{-1}$ and phenylalanine at $21.6 \pm 0.6 \mu \mathrm{mol} \cdot \mathrm{kg}^{-1} \cdot \mathrm{h}^{-1}$. Breath samples were collected in a small anesthesia bag using a facemask and a low resistance Rudolph valve (15) and then transferred into the sampling tube. The rate of carbon dioxide production $\left(\mathrm{VCO}_{2}\right)$ was measured during the basal period and after enteral feeding by using a DeltaTrac II indirect calorimeter (SensorMedics; Yorba Linda, CA) $(15,16)$.

Premature infants. As per the clinical practice, premature infants were started on $10 \%$ dextrose water at birth and changed to parenteral nutrition between 24 and $36 \mathrm{~h}$ (Fig. 1B). Babies were on parenteral amino acid solution (TrophAmine B. Braun Medical, Irvine, CA) at $3 \mathrm{~g} \mathrm{~kg}^{-1} \cdot \mathrm{d}^{-1}$ for $24 \mathrm{~h}$ before the tracer study. Cysteine hydrochloride was added at $40 \mathrm{mg} \cdot \mathrm{g}^{-1}$ amino acid. Preexisting indwelling vascular catheters, placed for clinical reasons, were used to infuse the tracers and to collect blood samples. After obtaining the basal samples, the tracer solutions were infused for $5 \mathrm{~h}$. Breath samples were collected by placing a plastic cannula attached to a $20-\mathrm{mL}$ syringe near the external nares. The expired air was drawn in the syringe and transferred into a sampling tube. During the tracer study, babies received parenteral amino acids $3.1 \pm 0.5 \mathrm{~g} \mathrm{~kg}^{-1} \cdot \mathrm{d}^{-1}$, methionine $24 \pm 0.4 \mu \mathrm{mol} \mathrm{kg}{ }^{-1} \cdot \mathrm{h}^{-1}$, phenylalanine $30 \pm 5 \mu \mathrm{mol} \mathrm{kg}{ }^{-1} \cdot \mathrm{h}^{-1}$, and cysteine $33 \pm 6 \mu \mathrm{mol} \mathrm{kg}{ }^{-1} \cdot \mathrm{h}^{-1}$.

The tracers were infused as follows: $\left[1{ }^{13} \mathrm{C}\right]$ methionine (Prime: 2.9 $\mu \mathrm{mol} \cdot \mathrm{kg}^{-1}$; Constant rate $\left.1.8 \mu \mathrm{mol} \mathrm{kg}{ }^{-1} \cdot \mathrm{h}^{-1}\right),\left[{ }^{2} \mathrm{H}_{3}\right.$ methyl] methionine (Prime: $2.9 \mu \mathrm{mol} \cdot \mathrm{kg}^{-1}$; Constant rate $1.8 \mu \mathrm{mol} \mathrm{kg}{ }^{-1} \cdot \mathrm{h}^{-1}$ ) and $\left[{ }^{2} \mathrm{H}_{5}\right]$ phenylalanine (Prime: $4 \mu \mathrm{mol} \mathrm{kg}{ }^{-1}$; Constant rate $4 \mu \mathrm{mol} \mathrm{kg}{ }^{-1} \mathrm{~h}^{-1}$ ). A priming dose of $60-\mu \mathrm{mol}$ of $\mathrm{NaH}\left[{ }^{13} \mathrm{C}_{3} \mathrm{O}_{3}\right.$ was given to achieve an early isotopic steady state in the bicarbonate pools. Initial data showed that this priming dose of sodium bicarbonate was high for the fasting state and therefore the dose was reduced to $25 \mu \mathrm{mol}$ in subsequent $(n=5)$ studies. Two full term infants were studied without a priming dose of sodium bicarbonate. Complete fasting and feeding data on transsulfuration were obtained in seven full term infants, while data in the fed state could be calculated on all infants. In full term infants, blood and breath samples were collected every 15 min between 150 and $180 \mathrm{~min}$ (fast) and between 390 and $420 \mathrm{~min}$ (feed). Samples from premature infants were collected every 30 min between 240 and 300 min. Samples of the tracer infusates were obtained for quantitative analysis and to test for sterility.

Analytical procedures. Blood glucose was measured by the glucose oxidase method using a glucose/lactate analyzer (Yellow Springs Instruments, Yellow Springs, OH). The concentration of total homocysteine, total cysteine and of amino acids in the plasma and infusates were measured by high performance liquid chromatography (HPLC) $(15,17)$. Plasma insulin levels were determined using a human plasma insulin ELISA kit (Millipore; Billerica, MA).

Gas chromatography-mass spectroscopy analysis. The methodology used to measure the enrichment of amino acid tracers in the plasma has been described (15-17). The $\mathrm{m} / \mathrm{z} 250(\mathrm{~m}+0)$ and $255(\mathrm{~m}+5)$ were monitored to measure the enrichment of $\left[{ }^{2} \mathrm{H}_{5}\right]$ phenylalanine. The mass-to-charge $(\mathrm{m} / \mathrm{z})$ ratios $234(\mathrm{~m}+0), 235(\mathrm{~m}+1), 236(\mathrm{~m}+2), 237(\mathrm{~m}+3)$ and $238(\mathrm{~m}+4)$ were monitored to quantify unlabeled and labeled methionine. The mass $235(\mathrm{~m}$ $+1)$ represented the enrichment of $\left[1-{ }^{13} \mathrm{C}\right]$ methionine and the mass $237(\mathrm{~m}+$ 3) represented the enrichment of $\left[{ }^{2} \mathrm{H}_{3}\right.$ methyl]methionine. Multiple linear regression analyses were performed to calculate the relative enrichments and correction for natural abundance of $\mathrm{m}+1\left(\left[1-{ }^{13} \mathrm{C}\right]\right.$ tracer $)$ and $\mathrm{m}+3$ $\left(\left[\mathrm{C}^{2} \mathrm{H}_{3}\right]\right.$ methyl)methionine $(18,19)$, using an in-house developed software (by J. Kim). Enrichment of ${ }^{13} \mathrm{C}$ in the carbon dioxide, which was quantified by isotope ratio mass spectrometry (Metabolic Solutions; Nashua, $\mathrm{NH}$ ). The ${ }^{13} \mathrm{C}$ enrichment of homocysteine in plasma was measured as described by Davis et al. (20).

The rate of appearance ( $\mathrm{Ra})$ of phenylalanine was calculated by tracer dilution during isotopic steady state (21). Phenylalanine Ra from protein breakdown was calculated by subtracting the exogenously administered phenylalanine from total phenylalanine Ra.

The various components of methionine metabolism were calculated as described by Storch et al. and MacCoss et al. $(19,22,23)$. The Ra of methionine estimated from the dilution of carboxyl labeled tracer $(\mathrm{Qc})$ represents methionine entering the circulation from proteolysis and from exogenous, enteral or parenteral, source. The carboxyl label is retained during the conversion of methionine to homocysteine (transmethylation) or back to methionine (remethylation). In contrast, the methyl label is lost during transmathylation and replaced by unlabeled methyl group during remethylation. Therefore, the Ra of methionine estimated from the dilution of $\left[\mathrm{C}^{2} \mathrm{H}_{3}\right]$ methionine is a sum of methionine released from protein breakdown, and the methionine that is exogenously administered plus the amount that is synthesized by methylation of homocysteine.

$\mathrm{Ra}$ (carboxyl tracer) or $\mathrm{Q}_{\mathrm{C}}=\mathrm{B}+\mathrm{I}$, where $\mathrm{B}$ is the appearance of methionine via protein breakdown and $\mathrm{I}$ is the methionine administered exogenously.

Ra (methyl tracer) or $\mathrm{Q}_{\mathrm{M}}=\mathrm{B}+\mathrm{I}+\mathrm{RM}$, where $\mathrm{RM}$ is the rate of remethylation of methionine from homocysteine. The difference between $Q_{M}$ and $Q_{C}$ represents the rate of remethylation: $Q_{M}-Q_{C}=R M$.

The rate of transsulfuration was assumed to be equal to the rate of oxidation of methionine and was estimated from the $\mathrm{Ra}{ }^{13} \mathrm{C}$ of $\left[1-{ }^{13} \mathrm{C}\right]$ methionine tracer in the expired $\mathrm{CO}_{2}(22,23)$. We could not perform satisfactory respiratory calorimetry estimates in the low birth weight (LBW) infants. Therefore, the average $\mathrm{VCO}_{2}$ data $\left(6 \mathrm{~mL} \mathrm{~kg}^{-1} \mathrm{~min}^{-1}\right)$ from the literature (24-26) were used. The calculations for the rate of oxidation have been described (16). It is assumed that during the formation of cysteine, an equimolar quantity of alpha-ketobutyrate is formed and is oxidized to $\mathrm{CO}_{2}$ in the tricarboxylic acid cycle $(19,23)$.

We did not correct the kinetic data for the intracellular enrichments of methionine; therefore, our estimates of transmethylation and transsulfuration are lower than actual. We did measure the plasma homocysteine enrichments as an index of intracellular $\left[1-{ }^{13} \mathrm{C}\right]$ methionine enrichment. However, homocysteine enrichments were not measured at all time points and, therefore, cannot be used as a measure of isotopic plateau.

We did not adjust for possible $\mathrm{CO}_{2}$ retention, because our previous data and those of others from healthy adults showed no significant retention of tracer during parenteral glucose infusion (27). The use of a $20 \%$ tracer retention factor would only increase our estimates of transsulfuration.

Statistical analysis. All data are presented as mean \pm SD. Group comparisons were made using parametric and nonparametric statistical methods with Statistix software (Analytical Software; La Jolla, CA). 
Table 2. Plasma amino acid concentration in full term and premature infants

\begin{tabular}{lccc}
\hline & \multicolumn{2}{c}{ Full term babies } & Premature infants \\
\cline { 2 - 3 } & Fast & $\begin{array}{c}\text { Feed } \\
(n=18)\end{array}$ & $\begin{array}{c}\text { during parenteral } \\
\text { nutrition }(n=9)\end{array}$ \\
\hline Glutamate & $22 \pm 7$ & $24 \pm 6$ & $35 \pm 16$ \\
Aspartate & $48 \pm 11$ & $52 \pm 9^{*}$ & $10 \pm 2$ \\
Serine & $141 \pm 43$ & $152 \pm 41$ & $194 \pm 70$ \\
Glutamine & $770 \pm 146$ & $808 \pm 147$ & $450 \pm 150$ \\
Glycine & $263 \pm 83$ & $262 \pm 73$ & $266 \pm 78$ \\
Histidine & $63 \pm 19$ & $67 \pm 18$ & $94 \pm 28$ \\
Threonine & $129 \pm 44$ & $137 \pm 42$ & $200 \pm 102$ \\
Citrulline & $17 \pm 7$ & $14 \pm 5 \dagger$ & $23 \pm 13$ \\
Alanine & $181 \pm 55$ & $217 \pm 57 \dagger$ & $157 \pm 40$ \\
Arginine & $55 \pm 20$ & $61 \pm 19 \dagger$ & $143 \pm 57$ \\
Tyrosine & $69 \pm 21$ & $75 \pm 18^{*}$ & $117 \pm 75$ \\
Valine & $110 \pm 25$ & $123 \pm 18^{*}$ & $221 \pm 48$ \\
Taurine & $41 \pm 16$ & $42 \pm 14$ & $37 \pm 12$ \\
Tryptophan & $31 \pm 5$ & $31 \pm 5$ & $38 \pm 10$ \\
Methionine & $31 \pm 6$ & $35 \pm 5 \dagger$ & $63 \pm 30$ \\
Phenylalanine & $61 \pm 11$ & $66 \pm 8^{*}$ & $84 \pm 28$ \\
Isoleucine & $36 \pm 9$ & $44 \pm 7 \dagger$ & $74 \pm 15$ \\
Leucine & $64 \pm 13$ & $73 \pm 11 \dagger$ & $144 \pm 25$ \\
Ornithine & $42 \pm 17$ & $56 \pm 22 \dagger$ & $153 \pm 75$ \\
Lysine & $115 \pm 32$ & $133 \pm 33 \dagger$ & $202 \pm 56$ \\
\hline
\end{tabular}

Mean $\pm \mathrm{SD}$; fast vs. fed: $* p<0.05 ; \dagger p<0.01$; premature infants amino acid concentrations were significantly different $(p<0.05$ to $p<0.001)$ compared with full term infants.

\section{RESULTS}

All infants were in stable clinical state and tolerated the procedures well.

Plasma amino acids and insulin concentrations. In full term babies, in response to feeding there was a significant increase in the concentration of essential amino acids (leucine, isoleucine, valine, phenylalanine, methionine and arginine), and of certain nonessential amino acids, i.e. ornithine, citrulline, alanine aspartate and glutamate (Table 2). The plasma amino acid concentrations of preterm infants were significantly higher when compared with full term infants in the fed state, except for glutamine and alanine, which were significantly lower.

The plasma concentration of homocysteine (fast $5.0 \pm 1.2$, fed $5.2 \pm 1.3 \mu \mathrm{mol} \cdot \mathrm{L}^{-1}$ ), cysteine (fast $311.0 \pm 39.2$, fed $321.5 \pm 31.1 \mu \mathrm{mol} \cdot \mathrm{L}^{-1}$ ), and taurine did not change in response to formula feeding.

The concentration of plasma insulin of full term infants was $3.5 \pm 2.1$ and $4.2 \pm 2.3 \mu \mathrm{U} / \mathrm{mL}$ before and during feeds, respectively. In preterm infants, the insulin levels were $11.1 \pm 7.0 \mu \mathrm{U} / \mathrm{mL}$.

Amino acid kinetics. Isotopic tracer plateaus were reached in the plasma, for methionine and phenylalanine both in preterm and full term infants (Fig. 2).

Phenylalanine. The Ra of phenylalanine in full term infants during fasting $\left(72.6 \pm 10.8 \mu \mathrm{mol} \cdot \mathrm{kg}^{-1} \cdot \mathrm{h}^{-1}\right)$ was similar to that reported by us previously (Table 3$)(15,28)$. The total Ra of phenylalanine remained unchanged during feeding (Table 3). Assuming complete absorption of phenylalanine from the gut, the calculated endogenous Ra of phenylalanine was significantly less than that during fasting, suggesting a suppression of whole body proteolysis.
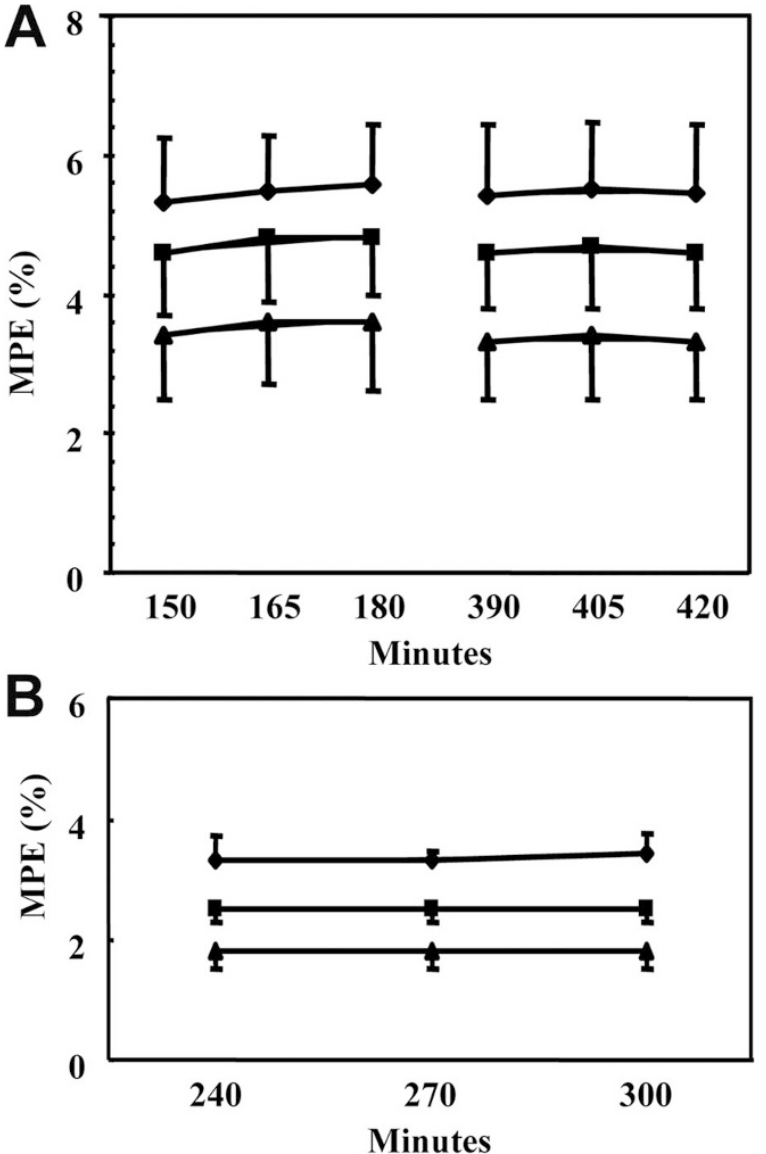

Figure 2. Isotopic tracer enrichments in the plasma in full term babies $(A)$ and preterm babies $(B)$ MPE: moles \% excess. $\left.{ }^{2} \mathrm{H}_{5}\right]$ phenylalanine, $\left[1-{ }^{13} \mathrm{C}\right]$ methionine, $\boldsymbol{\Delta}\left[\mathrm{C}^{2} \mathrm{H}_{3}\right]$ methionine.

Table 3. Phenylalanine and methionine kinetics

\begin{tabular}{ccc}
\hline & $\begin{array}{c}\text { Term } \\
(n=18)\end{array}$ & $\begin{array}{c}\text { Preterm } \\
(n=9)\end{array}$ \\
\hline RA phenylalanine & & - \\
Fast & $72.6 \pm 10.8$ & $128.9 \pm 34.9$ \\
Fed (total) & $73.2 \pm 13.3$ & $98.7 \pm 37.6 \dagger$ \\
Fed (endo) & $52.3 \pm 13.3^{*}$ & \\
Ra methionine & & \\
$\quad\left(\left[1{ }^{13} \mathrm{C}\right]\right.$ tracer $)$ & $36.2 \pm 7.3$ & - \\
Fast & $37.0 \pm 7.0$ & $54.4 \pm 25.8 \dagger$ \\
Fed (total) & $23.4 \pm 7.1^{*}$ & \\
Fed (endo) & & $100.1 \pm 19.31$ \\
Ra methionine & & $76.3 \pm 20.4 \dagger$ \\
$\quad\left[\mathrm{C}^{2} \mathrm{H}_{3}\right]$ tracer $)$ & $53.3 \pm 12.5$ & \\
Fast & $55.9 \pm 14.2$ & \\
Fed (total) & $42.4 \pm 14.3^{*}$ & \\
Fed (endo) & & \\
\hline
\end{tabular}

Mean $\pm \mathrm{SD}, \mu$ moles $\cdot \mathrm{kg}^{-1} \cdot \mathrm{h}^{-1}$.

endo, endogenous.

* Significantly different than fast, paired $t<0.001$

$\dagger$ Significantly different from full term babies, $p<0.006$.

In contrast to the full term babies, the Ra's of phenylalanine, both total and endogenous, was significantly higher in the preterm infants, suggesting a higher rate of protein breakdown.

Methionine. Using $\left[1-{ }^{13} \mathrm{C}\right]$ methionine tracer, the $\mathrm{Ra}$ of methionine in full term infants during fasting was $36.2 \pm 7.3$ 
Table 4. Transmethylation and transsulfuration of methionine in the newborn infant

\begin{tabular}{cccccc}
\hline & $\begin{array}{c}\text { Methylation } \\
\left(\mu \mathrm{mole} \cdot \mathrm{kg}^{-1} \cdot \mathrm{h}^{-1}\right)\end{array}$ & $\begin{array}{c}\mathrm{VCO}_{2} \\
\left(\mathrm{mmole} \cdot \mathrm{kg}^{-1} \cdot \mathrm{h}^{-1}\right)\end{array}$ & $\begin{array}{c}\mathrm{CO}_{2} \text { from } \\
\text { methionine }(\%)\end{array}$ & $\begin{array}{c}\text { Transsulfuration } \\
\left(\mu \mathrm{mole} \cdot \mathrm{kg}^{-1} \cdot \mathrm{h}^{-1}\right)\end{array}$ & $\begin{array}{c}\text { Transmethylation } \\
\left(\mu \mathrm{mole} \cdot \mathrm{kg}^{-1} \cdot \mathrm{h}^{-1}\right)^{*}\end{array}$ \\
\hline Full term & $26.0 \pm 10.7$ & $17.3 \pm 2.9$ & $0.039 \pm 0.03$ & $6.0 \pm 4.4$ & $32 \pm 14$ \\
Fast (6) & $18.8 \pm 13.5$ & $18.7 \pm 3.1$ & $0.029 \pm 0.01$ & $4.1 \pm 2.1$ & $21.7 \pm 13.2$ \\
$\begin{array}{c}\text { Fed (14) } \\
\text { Preterm }\end{array}$ & $35.0 \pm 17.6$ & $16.1 \dagger$ & $0.18 \pm 0.07$ & $24.9 \pm 9.9$ & $57.2 \pm 14.8$ \\
TPN (7) & & & & \\
\hline
\end{tabular}

* SAM dependent transmethylation.

$\dagger$ Average data from Refs. (24-26).

$\mu \mathrm{mol} \cdot \mathrm{kg}^{-1} \cdot \mathrm{h}^{-1}$. Mixed nutrient feeding did not have any significant impact on the total Ra of methionine. The calculated $\mathrm{Ra}$ of methionine from proteolysis was significantly less in the fed state. Ra methionine estimated using $\left[\mathrm{C}^{2} \mathrm{H}_{3}\right]$ methionine tracer was higher than that estimated using $\left[1-{ }^{13} \mathrm{C}\right]$ methionine tracer (Table 3). The $\mathrm{Ra}$ of methionine was significantly higher in preterm infants, using either tracer.

The ratio of endogenous methionine:phenylalanine Ra for both preterm and full term infants, $\sim 0.5$, was similar to that reported in mixed animal proteins, $\sim 0.48$ (29).

${ }^{13} \mathrm{C}$ enrichment of plasma homocysteine. The ${ }^{13} \mathrm{C}$ enrichment of plasma homocysteine was measured in 10 full term infants to examine the relation between the intracellular and extracellular enrichments of methionine (22). ${ }^{13} \mathrm{C}$ enrichment of total homocysteine in the plasma at 180 and $420 \mathrm{~min}$ of tracer infusion was $1.37 \pm 0.37$ and $2.32 \pm 0.48 \mathrm{~mol} \%$ excess, or 30 and $53 \%$, respectively, of the corresponding plasma methionine enrichment. In the preterm infants, plasma homocysteine enrichment at $4.5 \mathrm{~h}$ of tracer infusion was $1.15 \pm 0.14 \mathrm{~mol} \%$ excess, or $44 \%$ of the ${ }^{13} \mathrm{C}$ enrichment of plasma methionine.

Transmethylation and transsulfuration. The rate of methylation of homocysteine (RM) was variable (range 4-38 $\left.\mu \mathrm{mol} \cdot \mathrm{kg}^{-1} \cdot \mathrm{h}^{-1}\right)$. It was $17.1 \pm 12.1 \mu \mathrm{mol} \cdot \mathrm{kg}^{-1} \cdot \mathrm{h}^{-1}(n=$ 17) during fasting in the full term babies and did not change during feeding (Table 3). The rate of methylation of homocysteine $\left(35 \pm 18 \mu \mathrm{mol} \cdot \mathrm{kg}^{-1} \cdot \mathrm{h}^{-1}\right)$ was significantly higher $(p<0.03)$ in the prematurely born infants.

Because of the low contribution of ${ }^{13} \mathrm{CO}_{2}$ from methionine to expired carbon dioxide, reliable data could be obtained in only six infants during fasting (Table 4). An isotopic steady state in expired $\mathrm{CO}_{2}$ was evident during the fed state in all infants. Oxidation of methionine contributed less than $0.04 \%$ to the expired $\mathrm{CO}_{2}$. The rate of oxidation of methionine, or transsulfuration, was $6.0 \pm 4.4(n=6)$ and $4.1 \pm 2.1(n=14)$ $\mu$ mole $\mathrm{kg}^{-1} \cdot \mathrm{h}^{-1}$ during fasting and feeding, respectively. One full term baby showed no evidence of transsulfuration. The contribution of methionine to expired $\mathrm{CO}_{2}$ was higher $(0.18 \%)$ in preterm infants. We calculated the rate of transsulfuration using the average reported value of $\mathrm{VCO}_{2}(6 \mathrm{~mL}$ $\left.\mathrm{kg}^{-1} \cdot \min ^{-1},(24-26)\right)$. The rate of transsulfuration was higher in low birth weight infants as compared with those born at term gestation.

\section{DISCUSSION}

Our data show that transsulfuration of methionine was evident in healthy newborn infants born at term gestation and that the rate of transsulfuration is high in prematurely born neonates receiving parenteral amino acids. The rates of remethylation and transmethylation of methionine were high in newborn babies compared with those reported in adults $(19,23)$.

Our kinetic measurements are based upon quantification of tracer enrichments in the plasma compartment. Because the intracellular enrichments of methionine are likely to be less than that in the plasma, our measurements of transmethylation and transsulfuration are less than the actual rates. Although the enrichment of ${ }^{13} \mathrm{C}$ in homocysteine was measured and showed a significant plasma to intracellular gradient, we could not calculate intracellular kinetics, since a steady state enrichment of tracer in homocysteine could not be confirmed.

The Ra of essential amino acids in the plasma reflects the respective amino acid composition of the body proteins (29). We compared the relative $\mathrm{Ra}$ of phenylalanine with $\mathrm{Ra}$ of methionine measured by $\left[1-{ }^{13} \mathrm{C}\right]$ tracer. Both in the full term babies and in low birth weight babies, the ratio of Ra methionine/Ra phenylalanine was $\sim 0.5$. The similarity of this ratio to the reported amino acid composition of mixed body proteins $\sim 0.45$ (30) provides credence to our measurements. As reported by us $(15,28)$, the rates of phenylalanine turnover and hence the rate of whole body protein turnover were high in the neonate when compared with those in adults.

The rate of transsulfuration was estimated by the appearance of ${ }^{13} \mathrm{C}$ of carboxyl carbon of methionine in $\mathrm{CO}_{2}$ (19). Although methionine could also be decarboxylated via $s$-adenosyl methionine decarboxylase, the contribution of this pathway to mammalian methionine metabolism has been suggested to be negligible (2). Therefore, the oxidation of methionine reflects, for the most part, the transsulfuration pathway. The rate of transsulfuration was high in the low birth weight infants who were receiving parenteral amino acids with methionine when compared with the full term babies. These data are of interest when examined in the context of the expression and appearance of the enzymes, cystathione $\beta$ synthase and cystathione $\gamma$ lyase during development (3-7). Studies by Sturman and coworkers $(3,7)$ have shown that the cystathione gamma lyase activity was not detectable in the liver of the human fetus, but it was present in significant quantities in both prematurely born infants as well as those born at term gestation $(5,7)$. Cystathione $\gamma$ lyase activity could be induced by cAMP, glucagon and dexamethasone in vitro in explants of liver obtained from human fetuses in the second trimester (4). A recent study has confirmed these observations and shown that although the gene for cystathione $\gamma$ lyase is expressed in 
the liver in the human fetus, (mRNA was detected), but there was no CGL enzyme activity and the protein was not detectable in fetal, premature and full term neonatal liver tissue (6). CGL is present in fetal kidney but whether the renal activity can substitute for the lack of activity in the liver has not been determined (5). Thus, the gene for cystathione $\gamma$ lyase is transcribed in the liver during fetal life, but there is no enzyme activity until after birth. This is probably due to an inhibition of translation of CGL in the liver before birth. The mechanism that is responsible for this unusual type of regulation is not clear. The enzyme data thus suggest a low transsulfuration activity in the human newborn, which may be significant for premature infants. Our data show that in healthy full term infants, there is significant transsulfuration during the first $48 \mathrm{~h}$ after birth. The magnitude of transsulfuration was variable although it approximated that reported in healthy adults (19). This was likely related to the variability of the expression of enzymes involved because of difference in nutrient intake at this stage after birth.

The data in the premature infants are significant in that the magnitude of transsulfuration was 5-fold higher than was noted in full term babies. This high rate may be related to the large amount of methionine in the parenteral nutrition and represents the irreversible disposal of "unbalanced" methionine administered to these babies. Alternatively, it may also be related to the possible high demands for glutathione and creatine and may be controlled by the redox sensitive regulation of CBS (31).

The rates of methylation of homocysteine were higher in the neonates when compared with those reported in healthy adults $(19,22)$. The rates of remethylation and transmethylation were even higher in prematurely born infants. The high rates may be related to the high demands for methylation required for cell proliferation, growth, polyamine, and DNA synthesis (32). The data of the premature infants are particularly significant because both transmethylation and transsulfuration were high in these babies. Similar high rates of transmethylation and transsulfuration were seen in patients with severe brain injury (33), a protein catabolic state, and during parenteral amino acid administration (33). A high methionine load is expected to increase the concentration of $s$-adenosylmethionine (SAM). SAM is an allosteric activator of the CBS reactions $(31,34)$. Parenteral methionine infusion would therefore increase transsulfuration, as was seen in our study. SAM is also inhibitory for enzymes involved in methylation of homocysteine, i.e. betaine homocysteine methyltransferase (BHMT) and methylene tetrahydrofolate reductase (MTHFR) $(35,36)$. Therefore, the high rate of methylation of homocysteine was surprising. In this context, methylene tetrahydrofolate reductase activity was reported to be higher in the second trimester in human fetal liver and kidney as compared with adults, and betaine homocysteine methyltransferase specific activity was lower in fetal liver than in mature liver (37).

Transmethylation and remethylation of homocysteine in the methionine cycle does not result in net gain of methionine in the body. We propose that the high rate of remethylation of homocysteine to form methionine in the human newborn is

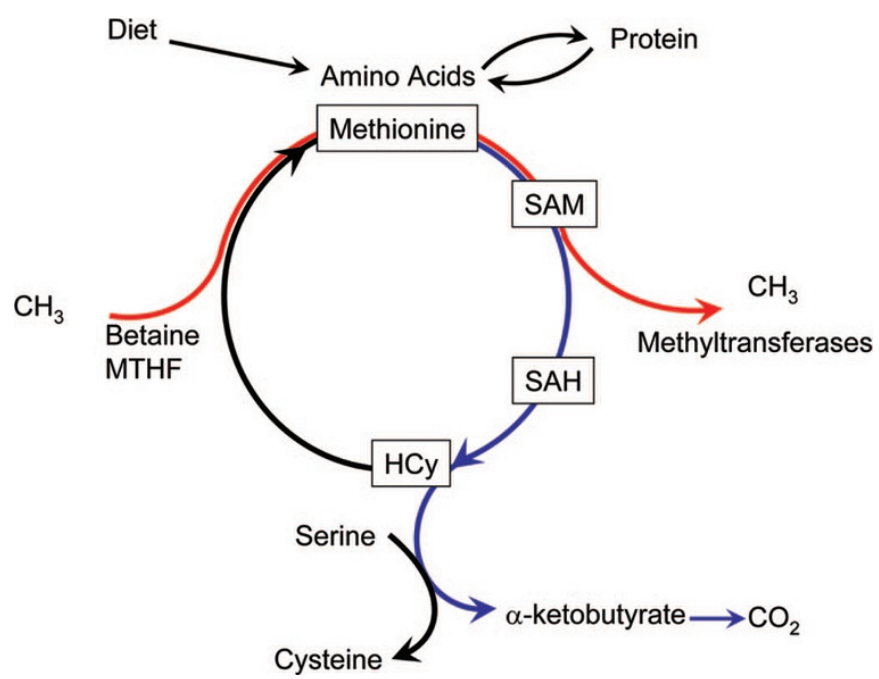

Figure 3. Methionine metabolism in vivo. Red indicates transfer of methyl groups from methyl donors; blue indicates the catabolism of methionine.

aimed at shuttling of the methyl groups from methyl donors, methylene tetrahydrofolate and betaine to SAM for various methyltransferase reactions (Fig. 3), whereas the transsulfuration is aimed at meeting the cysteine and glutathione requirement, and for the disposal of "excess" methionine.

Clinical implications. As discussed above, data from previous studies had suggested that the activity of both CGL and CBS were absent or low in the human fetus and in the newborn. In the prematurely born infant, the low activity was associated with higher concentrations of cystathionine and lower levels of cysteine in the plasma (38). In addition, red blood cells isolated from the premature infants at less than 32 wk of gestation synthesized glutathione from added methionine at a lower rate when compared with red cells from full term infants (39). Based upon such data L-cysteine has been suggested to be "conditionally" essential amino acids for neonates. However, cysteine supplementation in clinical studies has not been shown to impact nitrogen balance, weight gain or other clinical parameters (40). The negative clinical results of cysteine supplementation can be explained from our data showing significant rates of transsulfuration in the neonate. These data suggest that cysteine may not be a "conditionally" essential amino acid for the newborn. However, because of the marked variability in the rate of transsulfuration and because of its role in increasing the solubility of $\mathrm{Ca}$ and $\mathrm{P}$, it may be appropriate to continue to provide cysteine in parenteral nutrition.

Acknowledgments. We thank the staff of both the General Clinical Research Center and the Neonatal Intensive Care Unit for their help and support. The secretarial assistance from Mrs. Joyce Nolan is gratefully appreciated.

We thank Jaeyeon Kim for the use of IsoMet, software used for the calculation of relative enrichment of tracer isotopomer data. The software is available from jae.y.kim@case.edu.

\section{REFERENCES}

1. Brosnan JT, Brosnan ME 2006 The sulfur-containing amino acids: an overview. J Nutr 136:1636S-1640S 
2. Stipanuk MH 2004 Sulfur amino acid metabolism: pathways for production and removal of homocysteine and cysteine. Annu Rev Nutr 24:539-577

3. Sturman JA, Gaull G, Raiha NC 1970 Absence of cystathionase in human fetal liver: is cystine essential? Science 169:74-76

4. Heinonen K, Räihä NC 1974 Induction of cystathionase in human foetal liver. Biochem J 144:607-609

5. Zlotkin SH, Anderson GH 1982 The development of cystathionase activity during the first year of life. Pediatr Res 16:65-68

6. Levonen A-L, Lapatto R, Saksela M, Raivio KO 2000 Human cystathionine $\gamma$-lase: developmental and in vitro expression of two isoforms. Biochem J 347:291-295

7. Gaull G, Sturman JA, Raiha NC 1972 Development of mammalian sulfur metabolism: absence of cystathionase in human fetal tissues. Pediatr Res 6:538-547

8. van Goudoever JB, Sulkers EJ, Timmerman M, Huijmans JG, Langer K, Carnielli VP, Sauer PJ 1994 Amino acid solutions for premature neonates during the firs week of life: the role of N-acetyl-L-cysteine and N-acetyl-L-tyrosine. JPEN J Parenter Enteral Nutr 18:404-408

9. Helms RA, Christensen ML, Storm MC, Chesney RW 1995 Adequacy of sulfur amino acid intake in infants receiving parenteral nutrition. J Nutr Biochem 6:462466

10. Jacobs RL, Stead LM, Brosnan ME, Brosnan JT 2001 Hyperglucagonemia in rats results in decreased plasma homocysteine and increased flux through the transsulfuration pathway in liver. J Biol Chem 276:43740-43747

11. Jacobs RL, House JD, Brosnan ME, Brosnan JT 1998 Effects of streptozotocininduced diabetes and of insulin treatment on homocysteine metabolism in the rat Diabetes 47:1967-1970

12. Ratnam S, MacLean KN, Jacobs R, Brosnan ME, Kraus JP, Brosnan JT 2002 Hormonal regulation of cystathionine b-synthase expression in liver. J Biol Chem 277:42912-42918

13. Kalhan SC, Parimi PS 2002 Metabolism of glucose and methods of investigation in the fetus and newborn. In: Polin RA, Fox WW (eds) Fetal and Neonatal Physiology. Philadelphia, PA: WB Saunders \& Co, pp 357-372

14. Richardson DK, Gray JE, McCormick MC, Workman K, Goldmann DA 1993 Score for neonatal acute physiology: a physiologic severity index for neonatal intensive care. Pediatrics 91:617-623

15. Parimi PS, Gruca LL, Kalhan SC 2005 Metabolism of threonine in newborn infants Am J Physiol Endocrinol Metab 289:E981-E985

16. Denne SC, Kalhan SC 1987 Leucine metabolism in normal newborns. Am J Physio 253:E608-E615

17. Kalhan SC, Parimi PS, Gruca LL, Hanson RW 2005 Glutamine supplement with parenteral nutrition decreases whole body proteolysis in low birth weight infants. J Pediatr 146:642-647

18. Brauman JI 1966 Least squares analysis and simplification of multiple-isotope mass spectra. Anal Chem 38:607-610

19. Storch KJ, Wagner DA, Burke JF, Young VR $1990\left[1-{ }^{13} \mathrm{C}\right.$; methyl- $\left.{ }^{2} \mathrm{H}_{3}\right]$ methionine kinetics in humans: methionine conservation and cystine sparing. Am J Physiol 258:E790-E798

20. Davis SR, Stacpoole PW, Williamson J, Kick LS, Quinlivan EP, Coats BS, Shane B, Bailey LB, Gregory JF III 2004 Tracer-derived total and folate-dependent homocysteine remethylation and synthesis rates in humans indicate that serine is the main one-carbon donor. Am J Physiol Endocrinol Metab 286:E272-E279

21. Tserng K-Y, Kalhan SC 1983 Calculation of substrate turnover rate in stable isotope tracer studies. Am J Physiol 245:E308-E311
22. MacCoss MJ, Fukagawa NK, Matthews DE 2001 Measurement of intracellular sulfur amino acid metabolism in humans. Am J Physiol Endocrinol Metab 280:E947-E955

23. Storch KJ, Wagner DA, Burke JF, Young VR 1988 Quantitative study in vivo of methionine cycle in humans using $\left[\right.$ methyl- $\left.{ }^{2} \mathrm{H}_{3}\right]-$ and $\left[1-{ }^{13} \mathrm{C}\right]$ methionine. Am J Physiol 255:E322-E331

24. Thureen PJ, Phillips RE, DeMarie MP, Hoffenberg A, Bronstein MN, Spedale SB, Hay WW Jr 1997 Technical and methodological considerations for performance of indirect calorimetry in ventilated and non ventilated preterm infants. Crit Care Med 25:171-180

25. Fok TF, Gu J-S, Lim CN, Ng PC, Wong HL, So KW 2001 Oxygen consumption an resting energy expenditure during phototherapy in full term and preterm newborn infants. Arch Dis Child Fetal Neonatal Ed 85:F49-F52

26. Bauer J, Maier K, Linderkamp O, Hentschel R 2001 Effect of caffeine on oxygen consumption and metabolic rate in very low birth weight infants with idiopathic apnea. Pediatrics 107:660-663

27. Glamour TS, McCullough AJ, Sauer PJ, Kalhan SC 1995 Quantification of carbohydrate oxidation by respiratory gas exchange and isotopic tracers. Am J Physio 268:E789-E796

28. Parimi PS, Devapatla S, Gruca L, O'Brien AM, Hanson RW, Kalhan SC 2002 Glutamine and leucine nitrogen kinetics and their relation to urea $\mathrm{N}$ in newborn infants. Am J Physiol Endocrinol Metab 282:E618-E625

29. Bier DM 1989 Intrinsically difficult problems: the kinetics of body proteins and amino acids in man. Diabetes Metab Rev 5:111-132

30. Reeds PJ, Fjeld CR, Jahoor F 1994 Do the differences between the amino acid compositions of acute-phase and muscle proteins have a bearing on nitrogen loss in traumatic states? J Nutr 124:906-910

31. Prudova A, Bauman Z, Braun A, Vivitsky V, Lu SC, Banerjee R 2006 S adenosylmethionine stabilizes cystathionine $\beta$-synthase and modulates redox capacity. Proc Natl Acad Sci USA 103:6489-6494

32. Stead LM, Jacobs RL, Brosnan ME, Brosnan JT 2004 Methylation demand and homocysteine metabolism. Adv Enzyme Regul 44:321-333

33. Yu Y-M, Burke JF, Young VR 1993 A kinetic study of $\mathrm{L}^{-2} \mathrm{H}_{3}$-methyl-1- ${ }^{13} \mathrm{C}$ methionine in patients with severe burn injury. J Trauma 35:1-7

34. Miles EW, Kraus JP 2004 Cystathionine $\beta$-synthase: structure, function, regulation, and location of homocystinuria-causing mutations. J Biol Chem 279:29871-29874

35. Ou X, Yang H, Ramani K, Ara AI, Chen H, Mato JM, Lu SC 2007 Inhibition of human betaine-homocysteine methyltransferase expression by S-adenosylmethionine and methylthioadenosine. Biochem J 401:87-96

36. Jencks DA, Matthews RG 1987 Allosoteric inhibition of methylenetetrahydrofolate reductase by adenosylmethionine. J Biol Chem 262:2485-2493

37. Gaull GE, von Berg W, Raiha NC, Sturman JA 1973 Development of methyltransferase activities of human fetal tissues. Pediatr Res 7:527-533

38. White CW, Stabler SP, Allen RH, Moreland S, Rosenberg AA 1994 Plasma cysteine concentrations in infants with respiratory distress. J Pediatr 125:769-777

39. Viña J, Vento M, García-Sala F, Puertes IR, Gascó E, Sastre J, Asensi M, Pallardó FV 1995 L-cysteine and glutathione metabolism are impaired in premature infants due to cystathionase deficiency. Am J Clin Nutr 61:1067-1069

40. Soghier LM, Brion LP 2006 Cysteine, cysteine or N-acetylcysteine supplementation in parenterally fed neonates. Cochrane Database Syst Rev:CD004869 